\title{
Seroepidemiological Survey of Zoonotic Diseases in Small Mammals with PCR Detection of Orientia tsutsugamushi in Chiggers, Gwangju, Korea
}

\author{
Jung Wook Park', Jae Keun Chung1', Sun Hee Kim¹, Sun Ju Cho', Yi Deun Ha', So Hyang Jung1, Hye Jung Park', \\ Hyun Jae Song' ${ }^{2}$, Jung Yoon Lee ${ }^{2}$, Dong Min Kim³ ${ }^{3}$, Jah Pyus ${ }^{3}$, Dong Ryong Ha', Eun Sun Kim¹, Jae II Lee ${ }^{4, *}$ \\ 'Division of Infectious Disease Investigation, Health and Environment Research Institute of Gwangju City, Gwangju 61986, Korea; ${ }^{2}$ Clinical Pathology, \\ Gwangju Health University, Gwangju 62287, Korea; ${ }^{3}$ Department of Internal Medicine, School of Medicine, Chosun University, Gwangju 61452, \\ Korea; ${ }^{4}$ Department of Veterinary Public Health, College of Veterinary Medicine, Chonnam National University, Gwangu 62287, Korea
}

\begin{abstract}
Serosurveillance for zoonotic diseases in small mammals and detection of chiggers, the vector of Orientia tsutsugamushi, were conducted from September 2014 to August 2015 in Gwangju Metropolitan Area. Apodemus agrarius was the most commonly collected small mammals (158; 91.8\%), followed by Myodes regulus (8; 4.6\%), and Crocidura lasiura (6; 3.5\%). The highest seroprevalence of small mammals for 0 . tsutsugamushi $(41 ; 26.3 \%)$ was followed by hantaviruses (24; 15.4\%), Rickettsia spp. (22; 14.1\%), and Leptospira (2; 1.3\%). A total of 3,194 chiggers were collected from small mammals, and 1,236 of 3,194 chiggers were identified with 7 species of 3 genera: Leptotrombidium scutellare was the most commonly collected species $(585 ; 47.3 \%)$, followed by L. orientale (422; 34.1\%), Euchoengastia koreaensis (99; 8.0\%), L. palpale (58; 4.7\%), L. pallidum (36; 2.9\%), Neotrombicula gardellai (28; 2.3\%), and L. zetum (8; 0.6\%). L. scutellare was the predominant species. Three of 1,236 chigger mites were positive for 0 . tsutsugamushi by PCR. As a result of phylogenetic analysis, the 0 . tsutsugamushi strain of chigger mites had sequence homology of 90.1-98.2\% with Boryong. This study provides baseline data on the distribution of zoonotic diseases and potential vectors for the development of prevention strategies of vector borne diseases in Gwangju metropolitan area.
\end{abstract}

Key words: Leptotrombidium scutellare, Leptotrombidium orientale, Orientia tsutsugamushi, zoonotic disease, serosurveillance, rodent, soricomorph, chigger

\section{INTRODUCTION}

Zoonotic diseases in small mammals are a risk to humans who work or conduct recreational activities in field environments. During the fall period, typical zoonotic diseases in the Republic of Korea (ROK) are scrub typhus, hantaviruses, and leptospirosis [1]. They annually occur and cause acute, febrile illness to humans. Scrub typhus especially became increasingly important. According to the Korea Centers for Disease Control and Prevention (KCDC), chigger mite distribution has expanded from the south to central Korea. The number of scrub typhus patients increased from approximately 200 cases in the early 1990s, to > 10,000 cases in 2013 [1]. Known species of chigger mites include Leptotrombidium pallidum, L. scutellare, L.

- Received 19 November 2015, revised 26 April 2016, accepted 2 May 2016

*Corresponding author (jaeil@chonnam.ac.kr)

(c) 2016, Korean Society for Parasitology and Tropical Medicine

This is an Open Access article distributed under the terms of the Creative Commons Attribution Non-Commercial License (http://creativecommons.org/licenses/by-nc/4.0) which permits unrestricted non-commercial use, distribution, and reproduction in any medium, provided the original work is properly cited. palpale, L, orientale, L. zetum, Neotrombicula gardellai, Euchoengastia koreaensis, Neotrombicula japonica in the ROK. L. pallidum is the predominant species in the central region, and L. scutellare in the southern region [2]. In the world, there have been more than 20 antigenically distinct strains of scrub typhus reported [3]. The prototype Kato, Karp, and Gilliam strains were classified into a higher virulence group for humans. The Boryong type, which is a major strain in $\mathrm{ROK}$, was classified into a lower one [4].

Recent studies emphasized the relationships between a warming climate and distribution of primary scrub typhus vectors $[5,6]$, as well as detection of $O$. tsutsugamushi positive chigger mites, including new species as potential vectors of $O$. tsutsugamushi [7]. Therefore, this investigation focused on scrub typhus and other zoonotic diseases among small mammals and associated $O$. tsutsugamushi positive chigger mites. This information will provide baseline data for future investigation and information for development of zoonotic diseases mitigation strategies. 


\section{MATERIALS AND METHODS}

\section{Collection site}

From September 2014 to August 2015, small mammals were collected using Sherman live traps $\left(3^{\prime \prime} \times 3.5^{\prime \prime} \times 9^{\prime \prime}\right.$, USA) in 2 regions (Gwangsangu and Bukgu) of Gwangju Metropolitan Area (MA), ROK. Collection sites were just within the city perimeter. The 2 regions where traps were installed were in a similar environment. Both included 5 types of locations. The locations were fallow ground, a ridge between rice fields, a boundary between forest and field, around tombs, and around water. Traps were baited with biscuits covered with peanut butter and set up in the late afternoon, and collected from 8-10 a.m, the following morning. Gwangju MA surrounded by Chonnam Province is a densely populated area (Fig. 1).

\section{Collection of rodents and chiggers}

Traps positive for small mammals were numbered, placed into secure shipping containers, and then transported to the Health and Environment Research Institute of Gwangju MA.
Small mammals were euthanized using chloroform (Merck, West Point, Pennsylvania, USA) soaked cotton $(1 \times 1 \mathrm{~cm})$. Then, blood was centrifuged at 3,000 rpm for $20 \mathrm{~min}$, and serum was separated and maintained at $4^{\circ} \mathrm{C}$. Indirect immunofluorescence assay test (IFAT) and passive hemagglutination assay (PHA) were performed 24-36 hr after the small mammals were euthanized for antibody detection. The carcasses of the small mammals were hung over a glass bowl containing water to harvest chiggers, and chiggers were collected the following day.

\section{Detection of $O$. tsutsugamushi, hantantaviruses, and Rickettia spp. antibodies in small mammals}

A total of $10 \mu \mathrm{l}$ of sera from each small mammal was used for serial dilutions of 1:16, 1:32, 1:64, 1:128, 1:256, 1:512, 1:1,024, and 1:2,048 in PBS (pH 7.2). Diluted sera were deposited on an antigen spot slide, incubated at $37^{\circ} \mathrm{C}$ for $30 \mathrm{~min}$ in a humidified chamber, and then washed as in step 2. First, the slide was washed for 3 min with PBS, and second, washed for 3 min with distilled water to remove PBS salt. A total of 25
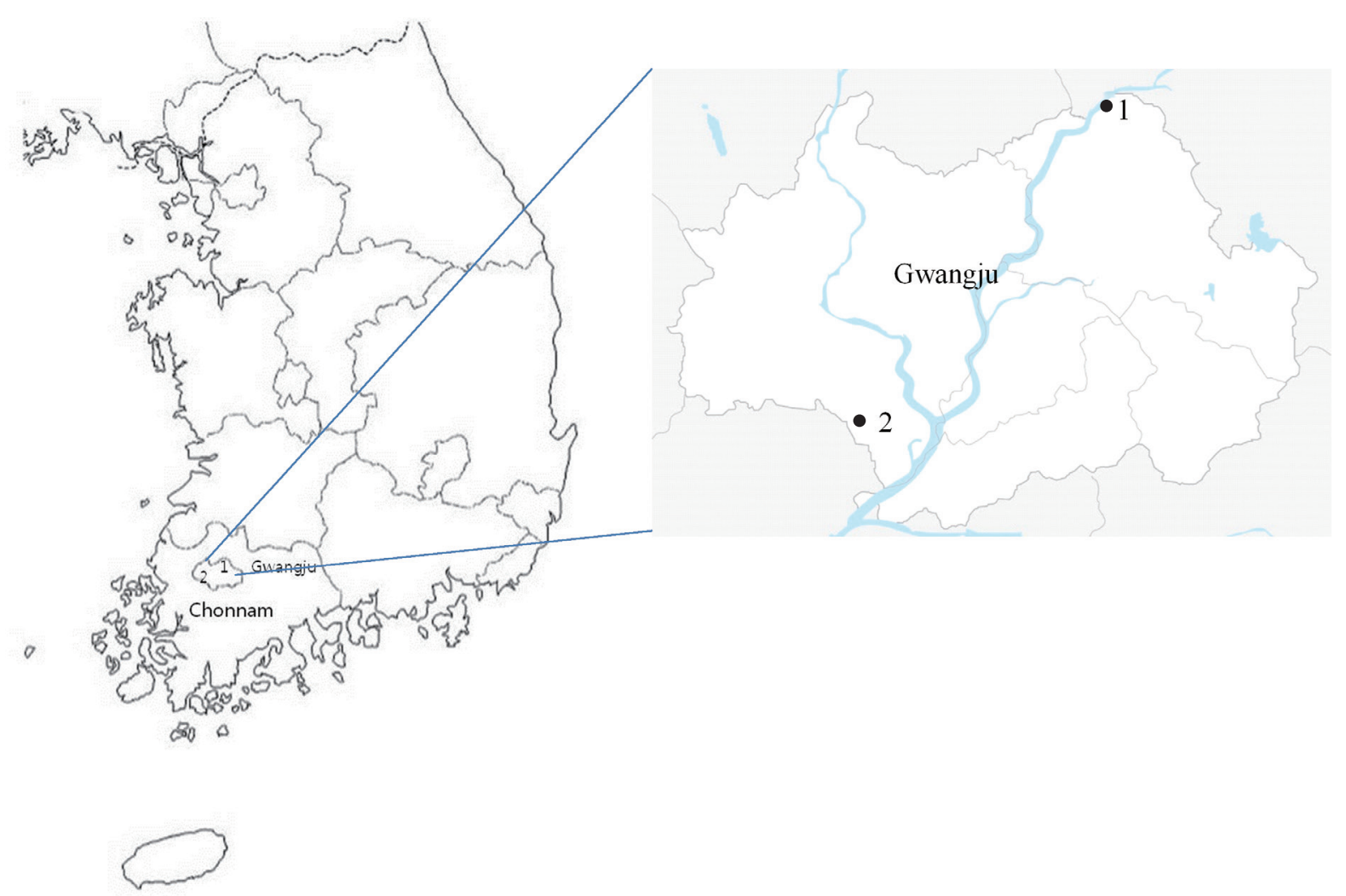

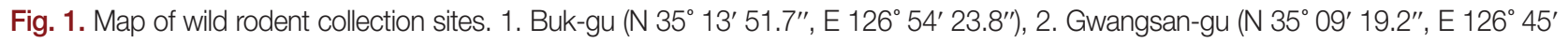
05.4") in Gwangju Metropolitan Area (MA), Republic of Korea. 
$\mu \mathrm{l}$ fluorescein isothiocyanate (FITC)-conjugated goat antimouse IgG (Sigma, St. Louis, Missouri, USA) was added to a spot slide, and the slides were incubated at $37^{\circ} \mathrm{C}$ for $30 \mathrm{~min}$ in a humidified chamber. The slides were washed for $3 \mathrm{~min}$ with PBS, distilled water, and then air-dried. After mounting medium (Sigma) was added to a spot slide, and covered with coverslip, the slides were examined for specific spots using a fluorescence microscope (Carl Zeiss, Oberkochen, Germany). A cutoff titer of 1:16 was used to identify seropositivity. Antigen spot slides for O. tsutsugamushi, hantaviruses, and Rickettsia spp. were provided by KCDC.

\section{Detection of Leptospira spp. antibodies in small mammals}

Genedia Lepto PHA (Green Cross, Seoul, Korea) kit reagents were used for detection of leptospirosis by PHA. A total of 25 $\mu \mathrm{l}$ serum from each small mammal was added to a 96-well plate, and diluted 1:80 in a dissolved solution of Genedia Lepto kit. A total of $75 \mu \mathrm{l}$ of sheep blood containing red blood cells sensitizied by Leptospira spp. was placed on a diluted serum for agglutination assay. Ag-Ab agglutination reaction in 1 : 80 tested positive for leptospirosis.

\section{Detection of $O$. tsutsugamushi in chigger mites by PCR}

The method used by Ree et al. [8] was applied for the detection of O. tsutsugamushi from individual chiggers. Individual chiggers were placed on a glass slide with PBS $10 \mu$. The chigger's internal contents were squeezed out with 2 fine pins and observed after suspension with $50 \mu \mathrm{l}$ PBS under stereomicroscope (Carl Zeiss). The chigger exoskeleton was mounted with polyvinylalcohol medium (Bioquip, Gardena, California, USA) and identified by Ree's fauna key [9]. Because it was difficult to perform with all chiggers, 30 chiggers per small mammals were used.

DNA was extracted from $20 \mu \mathrm{l}$ of chigger suspension using G-spin total DNA extraction kit (cat. no. 17046; Intron Biotechnology, Seoul, Korea). $200 \mu \mathrm{l}$ of lysis buffer and $10 \mu \mathrm{l}$ of proteinase $\mathrm{K}$ solution $(20 \mathrm{mg} / \mathrm{ml})$ was added to $20 \mu \mathrm{l}$ of chigger suspension. The lysate was incubated at $56^{\circ} \mathrm{C}$ on a heating block for $30 \mathrm{~min}$. After lysis, $200 \mu \mathrm{l}$ of binding buffer was added. Then, the mixture was incubated at $70^{\circ} \mathrm{C}$ for $5 \mathrm{~min}$. The mixture was applied to the spin column, and centrifuged at 13,000 rpm for $1 \mathrm{~min}$. After discarding the filtrate, washing buffer A was added to the spin column and centrifuged at 13,000 rpm for $1 \mathrm{~min}$. After discarding the flow-through, the column was placed into a $2.0 \mathrm{ml}$ collection tube. Washing buffer $B$ was added to the spin column and centrifuged at 13,000 rpm for $1 \mathrm{~min}$. After discarding the flow-through, placed column into a new $1.5 \mathrm{ml}$ collection tube, and a total of $50 \mu \mathrm{l}$ of elution buffer was added directly onto the membrane. After incubating for $1 \mathrm{~min}$ at room temperature, it was centrifuged for $1 \mathrm{~min}$ at 13,000 rpm to elute. DNA extract was stored at $-20^{\circ} \mathrm{C}$ until amplification.

PCR was performed as INNOPLEX TSUTSU detection kit (cat. No. IPC10040; Intron Biotechnology). The kit was designed using primer sets to detect the $475 \mathrm{bp}$ fragment gene encoding the $56 \mathrm{kDa}$ antigen of $O$. tsutsugamushi. The first PCR was performed with $2 \mu \mathrm{l}$ of DNA extract and $18 \mu \mathrm{l}$ of distilled water treated with diehyl pyrocarbonate (DEPC; Gendepot, Barker, Texas, USA) in the first PCR premix tube. PCR conditions were as follows: initial denaturation at $94^{\circ} \mathrm{C}$ for $5 \mathrm{~min}$; 40 cycle at $94^{\circ} \mathrm{C}$ for $30 \mathrm{sec}, 58^{\circ} \mathrm{C}$ for $30 \mathrm{sec}, 72^{\circ} \mathrm{C}$ for $40 \mathrm{sec}$; and final elongation at $72^{\circ} \mathrm{C}$ for 5 min using a Geneamp 9700 Biosystem (ABI, Foster City, California, USA). The second PCR was performed with $2 \mu \mathrm{l}$ of the first PCR product and $18 \mu \mathrm{l}$ of distilled water with DEPC in the second PCR premix tube. PCR conditions were as follows: initial denaturation at $94^{\circ} \mathrm{C}$ for $5 \mathrm{~min} ; 30$ cycle at $94^{\circ} \mathrm{C}$ for $30 \mathrm{sec}, 58^{\circ} \mathrm{C}$ for $30 \mathrm{sec}, 72^{\circ} \mathrm{C}$ for $40 \mathrm{sec}$, and final elongation at $72^{\circ} \mathrm{C}$ for $5 \mathrm{~min}$ using a Geneamp 9700 Biosystem (ABI). The final PCR products were evaluated by $1.5 \%$ agarose gel electrophoresis containing ethidium bromide.

The nucleotide sequence homology was aligned with sequence of previously published O. tsutsugamushi in Genbank by the BIOEDIT software program. The phylogenetic tree was generated by the neighbor-joining method (MEGA 6.0).

\section{RESULTS}

\section{Small mammal collection}

A total of 172 small mammals were collected. Apodemus agrarius was the most frequently collected 158 (91.8\%), followed by Myodes regulus 8 (4.6\%) and Crocidura lasiura 6 (3.5\%). Overall, monthly mean trap rate was $14.3 \%$ (range $7-26 \%$ ) (Table 1). For all periods, the trap rate for A. agrarius was higher for fallow ground (34.2\%), followed by around water (29.1\%), a boundary between forest and field (17.7\%), around a tomb (13.9\%), and a ridge between grain fields (5.1\%) (Table 2). 
Table 1. Number of small mammals captured by species (trap rate) in Gwangju CityMA, from September 2014 to August 2015

\begin{tabular}{|c|c|c|c|c|c|c|}
\hline \multirow{2}{*}{ Month } & \multirow{2}{*}{ No. traps } & \multirow{2}{*}{ Trapping rate (\%) } & \multicolumn{4}{|c|}{ No. of small mammals } \\
\hline & & & Apodemus agrarius & Myodes regulus & Crocidura lasiura & Total (\%) \\
\hline 2014. 9 & 100 & 10 & 10 & 0 & 0 & $10(10.0)$ \\
\hline 10 & 100 & 12 & 12 & 0 & 0 & 12 (12.0) \\
\hline 11 & 100 & 23 & 22 & 0 & 1 & 23 (23.0) \\
\hline 12 & 100 & 7 & 5 & 1 & 1 & $7 \quad(7.0)$ \\
\hline 2015. 1 & 100 & 18 & 14 & 3 & 1 & $18(18.0)$ \\
\hline 2 & 100 & 8 & 7 & 1 & 0 & $8 \quad(8.0)$ \\
\hline 3 & 100 & 11 & 10 & 1 & 0 & 11 (11.0) \\
\hline 4 & 100 & 10 & 9 & 1 & 0 & 10 (10.0) \\
\hline 5 & 100 & 26 & 22 & 1 & 3 & $26 \quad(26.0)$ \\
\hline 6 & 100 & 16 & 16 & 0 & 0 & $16(16.0)$ \\
\hline 7 & 100 & 18 & 18 & 0 & 0 & $18(18.0)$ \\
\hline 8 & 100 & 13 & 13 & 0 & 0 & $13(13.0)$ \\
\hline Total (\%) & 1,200 & 14.3 & $158(91.8)$ & $8(4.6)$ & $6(3.5)$ & $172(100)$ \\
\hline
\end{tabular}

Table 2. Number (\%) of small mammals captured by selected area in Gwangju MA, from September 2014 to August 2015

\begin{tabular}{|c|c|c|c|c|c|c|}
\hline \multirow[b]{2}{*}{ Species } & \multicolumn{6}{|c|}{ No. of small mammals (\%) } \\
\hline & Fallow ground & $\begin{array}{l}\text { A ridge between } \\
\text { rice fields }\end{array}$ & $\begin{array}{l}\text { Boundary between } \\
\text { forest and field }\end{array}$ & Around tomb & Around water & Total (\%) \\
\hline Apodemus agrarius & $54(34.2)$ & $8(5.1)$ & $28(17.7)$ & $22(13.9)$ & $46(29.1)$ & 158 \\
\hline Myodes regulus & 0 & 0 & $4(44.4)$ & $4(44.4)$ & $1(11.1)$ & 9 \\
\hline Crocidura lasiura & $1(20)$ & 0 & $1(20)$ & $2(40)$ & $1(20)$ & 5 \\
\hline Total (\%) & 55 (31.9) & $8(4.7)$ & $33(19.19)$ & $28(16.28)$ & $48(27.9)$ & 172 \\
\hline
\end{tabular}

Table 3. Number (\%) of small mammals seropositive for O. tsutsugamushi, hantaviruses, Rickettsia spp., and leptospirosis that were captured in Gwangju MA, from September 2014 to August 2015

\begin{tabular}{|c|c|c|c|c|c|c|c|c|c|c|}
\hline \multirow[b]{2}{*}{ Species } & \multirow[b]{2}{*}{$\begin{array}{l}\text { No. small } \\
\text { mammals } \\
\text { tested }\end{array}$} & \multirow[b]{2}{*}{$\begin{array}{l}\text { O. tsutsuga- } \\
\text { mushi }\end{array}$} & \multirow[b]{2}{*}{$\begin{array}{l}\text { Hanta- } \\
\text { viruses }\end{array}$} & \multirow[b]{2}{*}{$\begin{array}{l}\text { Leptospira } \\
\text { spp. }\end{array}$} & \multirow[b]{2}{*}{$\begin{array}{l}\text { Rickettsia } \\
\text { spp. }\end{array}$} & \multicolumn{5}{|c|}{ Mixed infection } \\
\hline & & & & & & $\begin{array}{l}\text { O. tsutsuga- } \\
\text { mushi/ } \\
\text { hanta- } \\
\text { viruses }\end{array}$ & $\begin{array}{l}\text { O. tsutsuga- } \\
\text { mushi/ } \\
\text { Rickettsia } \\
\text { spp. }\end{array}$ & $\begin{array}{l}\text { Hanta- } \\
\text { viruses/ } \\
\text { Leptospira } \\
\text { spp. }\end{array}$ & $\begin{array}{l}\text { Hanta- } \\
\text { viruses/ } \\
\text { Rickettsia } \\
\text { spp. }\end{array}$ & $\begin{array}{c}\text { O. tsutsuga- } \\
\text { mushi/ } \\
\text { Hantaviruses/ } \\
\text { Rickettsia spp }\end{array}$ \\
\hline $\begin{array}{l}\text { Apodemus } \\
\text { agrarius }\end{array}$ & 145 & $\begin{array}{c}37 \\
(25.5)\end{array}$ & $\begin{array}{c}23 \\
(15.9)\end{array}$ & $\begin{array}{c}2 \\
(1.4)\end{array}$ & $\begin{array}{c}22 \\
(15.2)\end{array}$ & $\begin{array}{c}9 \\
(6.2)\end{array}$ & $\begin{array}{c}7 \\
(4.8)\end{array}$ & $\begin{array}{c}1 \\
(0.7)\end{array}$ & $\begin{array}{c}3 \\
(2.1)\end{array}$ & $\begin{array}{c}1 \\
(0.7)\end{array}$ \\
\hline $\begin{array}{l}\text { Myodes } \\
\text { regulus }\end{array}$ & 7 & $\begin{array}{c}4 \\
(57.1)\end{array}$ & $\begin{array}{c}1 \\
(14.3)\end{array}$ & 0 & 0 & 0 & 0 & 0 & 0 & 0 \\
\hline $\begin{array}{l}\text { Crocidura } \\
\text { lasiura }\end{array}$ & 4 & 0 & 0 & 0 & 0 & 0 & 0 & 0 & 0 & 0 \\
\hline Total (\%) & 156 & 41 (26.3) & $24(15.4)$ & $2(1.3)$ & $22(14.1)$ & $9(5.8)$ & $7(4.5)$ & $1(0.6)$ & $3(1.9)$ & $1(0.6)$ \\
\hline
\end{tabular}

Seropositive rates for $O$. tsutsugamushi, hantaviruses, Rickettisia spp., and Leptospira spp. in small mammals

Blood samples were obtained from 156/172 (90.7\%). A total of 41/156 (26.3\%) were seropositive for O. tsutsugamushi followed by small mammals positive for hantaviruses (24/156, 15.4\%), Rickettsia spp. (22/156, 16.7\%), and Leptospira spp. (2/172, 1.3\%). Especially, tested 12 rodents were all positive for O. tsutsugamushi in October 2014. The prevalence for 4 vector-borne (deletion) infectious diseases was confirmed all the year round in Gwangju MA. Total 21 cases of mixed infections were confirmed in A. agrarius (Table 3).

\section{Seasonal distribution of chiggers and detection of O. tsutsugamushi by PCR}

A total of 2,772 chiggers were collected from 158 A. agrarius (Table 4). L. scutellare 579 (54.1\%) was the most commonly collected chiggers, followed by L. orientale 281 (1.8\%), E. koreaensis 94 (8.8\%), L. palpale 46 (4.3\%), L. pallidum 36 (3.3\%), and L. zetum 7 (0.7\%). The majority of L. scutellare were collected during the autumn (September-November, mean 5.6- 
Table 4. Number (mean number) of chigger mites collected from Apodemus agriarius in Gwangju MA, between September 2014 and August 2015

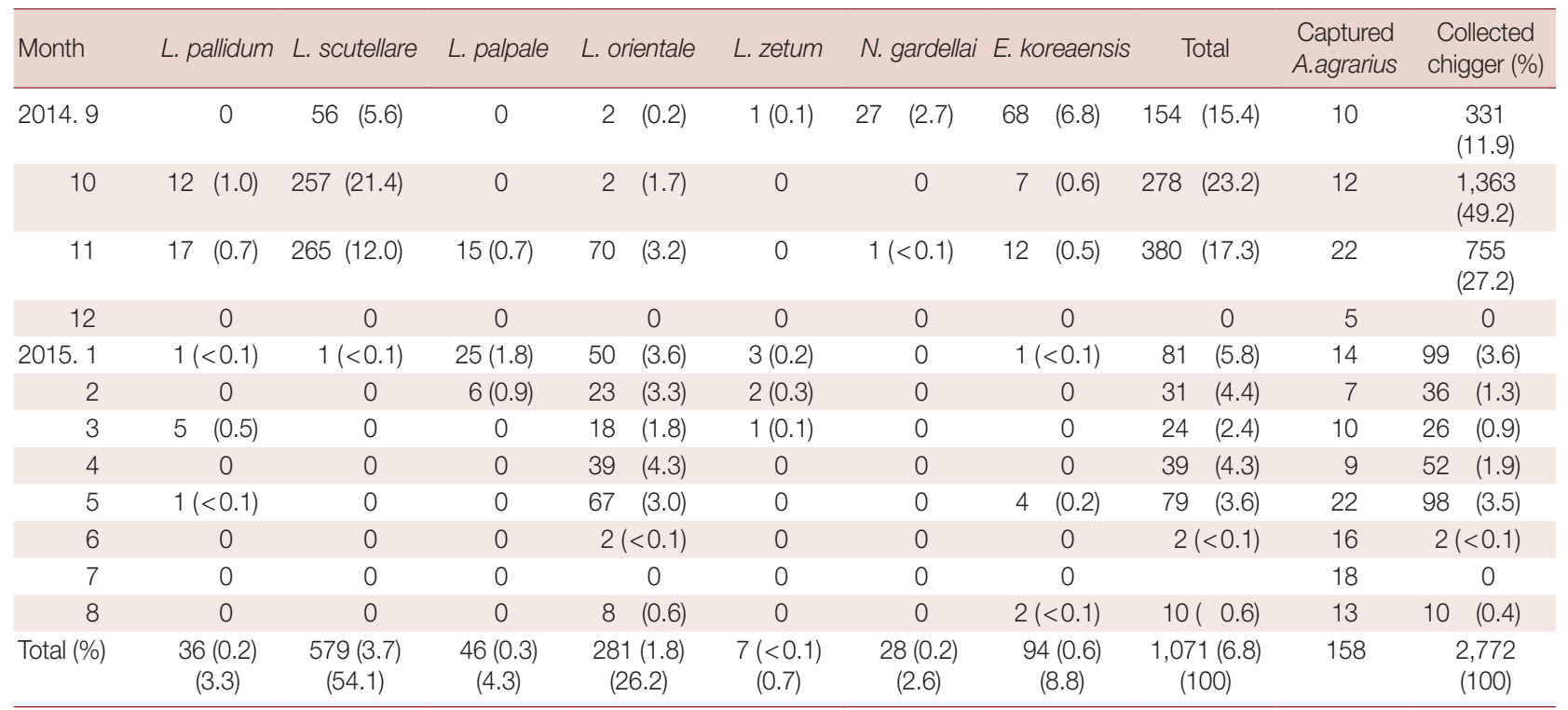

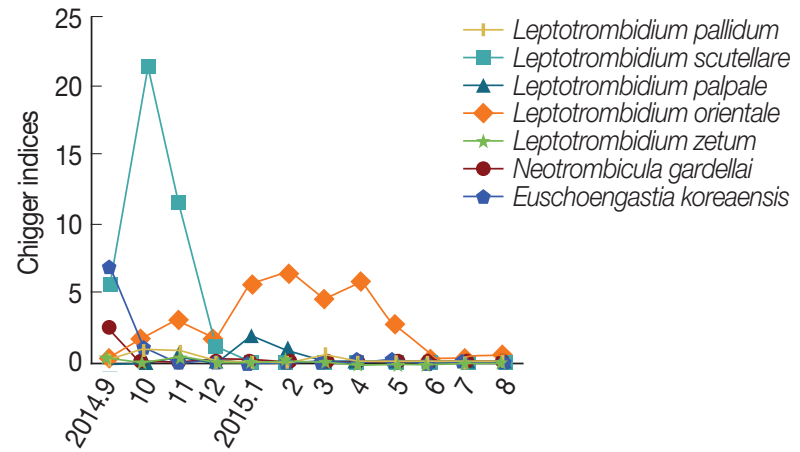

Fig. 2. Mean number of chigger mite species collected from Apodemus agrarius in Gwangju MA, from September 2014 to August 2015.

21.4), while L. orientale was collected in late autumn (October, mean 1.7) through spring (May, mean 3.0). A high number of E. koreaensis was collected in fall (September, 6.8), but infrequently during other months (Fig. 2).

The distribution of chiggers by species of small mammals was 7 chigger species on A. agrarius, 4 species on M. regulus, and no chiggers on C. lasiura (Table 5). A total of 3 chiggers $(0.24 \%)$ were positive for $O$. tsutsugamushi (Table 5). Each sequence (1,410 mite-1 L. scutellare, 1,410 mite-2 L. scutellare, 1,504 mite-3 L. orientale) showed homology of 90.1\%, 93.2\%, and $98.2 \%$ with the Boryong strain (accession no. L04956) (Fig. 3). Two L. scutellare collected from A. agrarius (September 2014), and 1 L. orientale from M. regulus (April 2015) were confirmed as positive for $O$. tsutsugamushi.

\section{DISCUSSION}

Seasonal serosurveillance of $O$. tsutsugamushi, hantavirues, Rickettsia spp., and Leptospira spp. in small mammals and a study on chiggers collected from small mammals were conducted. For all periods, A. agrarius was the most frequently collected species (91.8\%). Capture rates of A. agrarius were high for fallow ground area (34.2\%) and around water (29.1\%), places which were unmanaged and covered with $1 \mathrm{~m}$ cyperaceae. There were always several puddles in the fallow ground area, and this area was more likely to be damp than other areas. C. lasiura and M. regulus capture rates were high for the boundary between forest and field areas and the area around tombs, which were located in a hillier section than the fallow ground area. There was few grass bush in these areas. There were differences in species distribution by areas.

As shown in Table 3, the prevalence of scrub typhus was $25.5 \%$ in A. agrarius, lower than in surveys performed in Gyeonggi province, central part of ROK [10-12]. We confirmed evidence of infection of various zoonotic diseases in A. agrarius and observed evidence of scrub typhus and hantavirues in $M$. regulus. Evidence of antibodies to hantaviruses and Rickettsia spp. implies that Gwangju MA area is not free of other zoonotic diseases.

In chigger mite's distribution, L. scutellare was the predomi- 
Table 5. Numbers of tested chigger mites (no. positive) assayed for O. tsutsugamushi by PCR in Gwangju MA, from Sepember 2014 to August 2015

\begin{tabular}{lcccccccccc}
\hline Species & L. pallidum & L. scutellare & L. palpale & L. orientale & L. zetum & N. gardellai & E. koreaensis & Total & Infection rate Test rodent \\
\hline $\begin{array}{c}\text { Apodemus } \\
\text { agrarius }\end{array}$ & 36 & $579(2)$ & 46 & 281 & 7 & 28 & 94 & $1,071(2)$ & 0.19 & 158 \\
$\begin{array}{c}\text { Myodes } \\
\text { regulus }\end{array}$ & 0 & 6 & 12 & $141(1)$ & 1 & 0 & 5 & $165(1)$ & 0.59 \\
$\begin{array}{c}\text { Crocidura } \\
\text { lasiura }\end{array}$ & 0 & 0 & 0 & 0 & 0 & 0 & 0 & 0 & 0 & 6 \\
\begin{tabular}{l} 
Total \\
\hline
\end{tabular} & 36 & $585(2)$ & 58 & $422(1)$ & 8 & 28 & 99 & $1,236(3)$ & 0.24 & 172 \\
\hline
\end{tabular}

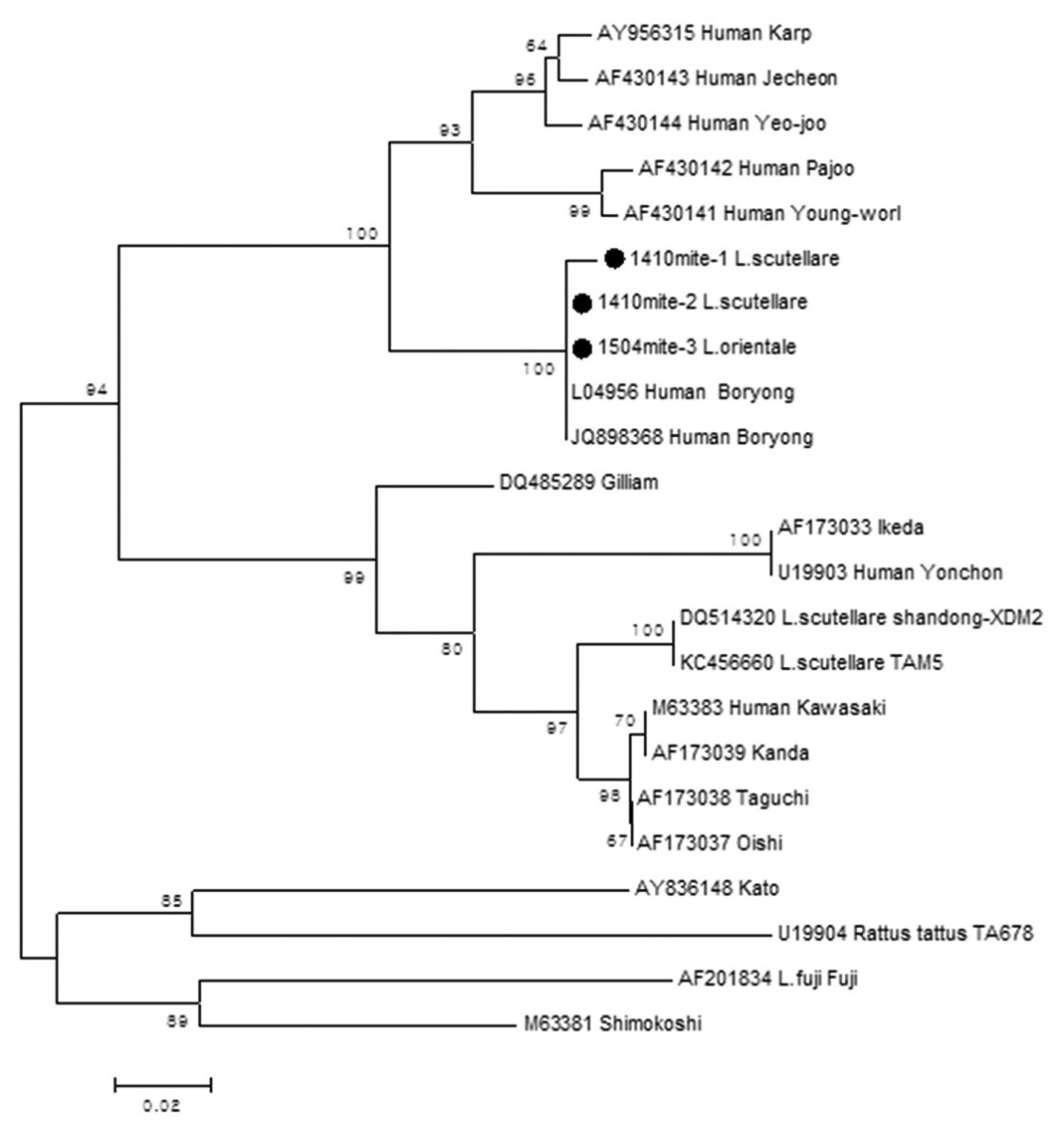

Fig. 3. Phylogenetic tree based on the nucleotide sequences of Orientia tsutsugamushi $56 \mathrm{kDa}$ genes. The Neighbor-joining tree was constructed under kimura-2 parameter model (bootstrap 1,000 replicate) using MEGA 6.0. Gwangju metropolitan area strains (1,410 mite-2 L. scutellare, 1,410 mite-1 L. scutellare, 1,504 mite-3 L. orientale) identified are marked with filled circle.

nant chigger from A. agrarius in Gwangju MA and was similar to the results at Chonnam province [13-15]. Meanwhile, L. pallidum was the predominant species in central parts of ROK [16-18]. As shown in Fig. 2, there was seasonal difference of chigger mite species collected from A. agrarius. L. scutellare was highest from October through November 2014, and high populations of $L$. scutellare may contribute to human transmission of scrub typhus in Gwangju MA area. L. orientale was highest in winter-spring seasons. This result indicates that the species of chigger mites could be affected by temperature and humidity.

Strains of scrub typhus show geographical variation. In ROK, the Boryong strain is known to be the predominant type in vectors and humans [3]. Our results showed that the 3 chiggers positive for scrub typhus were all Boryong strain. In our 
study, it was found that small mammals were the source of various zoonotic diseases, and L. scutellare contributed to high chigger indices during the fall period. To reduce risk of zoonotic disease in Gwangju MA, it is necessary to clear fallow ground near humans' living space (cutting grass, filling puddles) for rodent control, and to provide adequate protection to farm workers (long sleeve clothes, boots). More information must be relayed about the risk of vector borne zoonotic diseases. Because information from 2 sites was limited, more data are needed over years regarding the relationship of disease transmission on humans, additional site selection, and distribution of gravid small mammals. In the future, our data will be helpful to provde prevention strategies against the resurgence of vector borne zoonotic diseases.

\section{CONFLICT OF INTEREST}

We have no conflict of interest related to this work.

\section{REFERENCES}

1. Korea Centers for Disease Control and Prevention (K-CDC). Diseases Web Statistics System. Accessed at http://is.cdc.go.kr/ dstat/index.jsp. 31 December 2014.

2. Lee IY, Kim HC, Lee YS, Seo JH, Lim JW, Yong TS, Klein TA, Lee WJ. Geographical distribution and relative abundance of vectors of scrub typhus in the Republic of Korea. Korean J Parasitol 2009; 47: 381-386.

3. Kelly DJ, Fuerst PA, Ching WM, Richards AL. Scrub typhus: the geographic distribution of phenotype and genotypic variants of Orientia tsutsugamushi. Clin Infect Dis 2009; 48: 203-230.

4. Nakayama K, Kurokawa K, Fukuhara M, Urakami H, Yamamoto S, Yamazaki K, Ogura Y, Ooka T, Hayashi T. Genome comparison and phylogenetic analysis of Orientia tsutsugamushi strains. DNA Res 2010; 17: 281-291.

5. Lee CS. Climate Change. Seoul, Korea. Lifescience. 2002.

6. Shin HS. Climate change and health adapting strategies. Seoul, Korea. Korea Institute for Health and Social Affairs 2010; 54: 1-8.

7. Lee HI, Shim SK, Song BG, Choi EN, Hwang KJ, Park MY, Park C, Shin EH. Detection of Orientia tsutsugamushi, the causative agent of scrub typhus, in a novel mite species, Eushoengastia koreaensis, in Korea. Vector Borne Zoonotic Dis 2011; 11: 209-214.

8. Ree HI, Chang WH, Kee S, Lee IY, Jeon SH. Detection of Orientia tsutsugamushi DNA in individual trombiculids using polymerase chain reacntion in Korea. Med Entomol Zool 1997; 48: 197209.

9. Ree HI. Fauna and key to the chigger mites of Korea (Acarina: Trombiculidae and Leeuwenhoekiidae). Korean J Syst Zool 1990; 6: 57-70.

10. Cho EJ, Song JW, Baek LJ, Lee HW. Seroepidemiologic study on the reservoir animals of the etiologic agents of acute hemorrhagic diseases in Korea. Korea Univ Collect Disser 1990; 27: 116126.

11. Baek LJ, Song JW, Song KJ, Ko EY, Chung KM, Lee YJ. Serological study on rickettsial infection of wild rodents in Kyunggi and Kangwon province in Korea. Infect Chemother 1989; 30: 443449.

12. Kim HC, Lee IY, Chong ST, Richards AL, GU SH, Song JW, Lee JS, Klein TA. Serosurveillance of scrub typhus in small mammals collected from military training sites near the DMZ, northern Gyeonggi-do, Korea, and analysis of the relative abundance of chiggers from mammals examined. Korean J Parasitol 2010; 48: 237-243.

13. Song HJ. Environmental survey on the vectors and hosts of tsutsugamushi disease in Jeonnam province, Korea. Korean J Vet Serv 2012; 35: 183-189.

14. Song HJ, Kim KH, Kim SC, Hong SS, Ree HI. Population density of chigger mites, the vector of tsutsugamushi disease in Chollanam-do, Korea. Korean J Parasitol 1996; 34: 27-33 (in Korean).

15. Lee SH, Lee YS, Lee IY, Lim JW, Shin HK, Yu JR, Sim S. Monthly occurrence of vectors and reservoir rodents of scrub typhus in an endemic area of Jeollanam-do, Korea. Korean J Parasitol 2012; 50: 327-331.

16. Lee IY, Song HJ, Choi YJ, Shin SH, Choi MK, Kwon SH, Shin EH, Park C, Kim HC, Klein TA, Park KH, Jang WJ. Larval chigger mites collected from small mammals in 3 Provinces, Korea. Korean J Parasitol 2014; 52: 225-229.

17. Ree HI, Baek LJ, Lee HW, Back YH. Trombiculid mite from Apodemus agrarius caught at Pochun-gun, Gyeongggi Province and Chinhae-city, Kyongnam Province. Korean J Parasitol 1989; 27: 141-144.

18. Lee IY, Yoon SS, Ree HI. Seasonal distribution of chigger mites in the Kanghwa Island and Yongjong Island. Korean J Parasitol 1993; 31: 341-346. 
